\title{
Economics
}

\section{Economic Assessment of the Impact of Packaging Design on Consumption}

\author{
Bassam Charif Hamdar $^{1}$, Abeer Khalil ${ }^{2}$, Mohamad Bissani ${ }^{2}$, Natalie Kalaydjian ${ }^{3}$ \\ ${ }^{1}$ Department of Economics, Faculty of Business and Economics, American University of Science and Technology, Beirut, Lebanon \\ ${ }^{2}$ Department of Finance, Faculty of Business and Economics, American University of Science and Technology, Beirut, Lebanon \\ ${ }^{3}$ Department of Business Administration, Faculty of Business and Economics, American University of Science and Technology, Beirut, \\ Lebanon
}

Email address:

bhamdar@aust.edu.lb (B. C. Hamdar)

\section{To cite this article:}

Bassam Charif Hamdar, Abeer Khalil, Mohamad Bissani, Natalie Kalaydjian. Economic Assessment of the Impact ofPackaging Design on Consumption. Economics. Vol. 7, No. 2, 2018, pp. 27-33. doi: 10.11648/j.eco.20180701.15

Received: May 9, 2018; Accepted: May 24, 2018; Published: June 11, 2018

\begin{abstract}
Packaging has become itself a sales promotion tool for commercial organizations. Consumers are exposed to more than 20,000 product choices within a 30-minute shopping session. The objective of this paper is to determine the effect of packaging design on consumer purchasing behavior, along with the identification of the main aspects that contribute to the packaging of a product. Packaging is believed to leave a certain positive or negative impression on the consumer which greatly affects the sales and the market share of a commercial organization. Thus, it is important to take into consideration the effect of the packaging of a product on the consumers' buying behavior. By understanding how packaging affects the purchase decision, companies will be able to make the right decision when it comes to product packaging and presentation. This research identifies the relationship between the main variable, which is the consumer buying behavior, and the independent variables such as packaging elements and packaging quality. Upon distributing 150 structured questionnaires, primary research data was collected, and SPSS software was used to analyze and interpret the findings. The results of this research show the importance of having good packaging elements and quality in order to maintain a positive product image, and achieve a better market impact. Future research is proposed which can help in developing a better understanding of consumer buying response in relation to packaging elements and quality.
\end{abstract}

Keywords: Consumption, Packaging Design, Buying Behavior, Consumer Response

\section{Introduction}

In a perfectly competitive market where firms sell the same product, companies tend to increase their advertising and marketing power. The intention of any commercial organization is to develop brands in order to attract and retain the existing consumers [1].

Packaging has become itself a sales promotion tool for businesses to attract customers, and increase the product acceptability in the market [2]. Today, consumers are exposed to more than 20,000 product choices within a 30 minute shopping session [3]. Taking into consideration the impact of packaging, one can conclude that packaging is no more used to wrap a product and protect it from any damage, but to increase the product sale potential in the market.
Customers having the option to choose from a row of similar products with similar contents, they tend to choose the most appealing one. This is where packaging plays one of its most important roles. According to [4], packaging appeals to consumer attentiveness towards a certain brand and increases its image; moreover, it stimulates consumer's perceptions about the product.

Packaging works as an instrument for differentiation, and helps consumers to decide on a product from a wide range of parallel products, packaging also stimulates customers' buying behavior [5].

It is important for a commercial organization to understand the factors that influence the consumer buying behavior. It must also understand the role of the packaging elements towards the buying decision of a consumer. Market researches related to this topic help companies realize how 
the consumer buying behavior is affected by the packaging design, and thus, help them in creating a more desirable product package.

Companies must understand what influences consumers in their buying process. They must also understand what factors influence the buying behavior, and what is the role of the packaging elements in relation to the buying decision of consumers? Market research helps companies to create the 'right' packaging for a product, as well as the packaging elements that might be of importance to consumers.

The purpose of this research is conducted on the importance of the packaging elements, packaging quality, and their influence on consumer's buying behavior. This paper reveals the features of a packaging design which influence the consumer's choice when facing multiple choices of a similar product.

\section{Objectives of the Study}

This paper tries to analyze the most important elements of packaging that influence the buying decision process. Thus, the paper will try to:

Measure the role of packing elements on the consumers' intent to buy a product.

Determine the impact of the quality of the packaging materials on the buying behavior of consumers.

Research Questions and Hypotheses

This paper will try to answer the following research questions:

1. What is the impact of packing elements on the decision of a consumer to buy a certain product?

2. What is the effect of the quality of the package on the consumer buying behavior?

The paper will also try to test the following hypotheses:

H1: The consumer buying behavior is significantly affected by packaging elements.

$\mathrm{H} 2$ : The quality of the packaging material has a considerable effect on the buying behavior of consumers.

\section{Literature Review}

Packaging provides multidimensional functions. It offers knowledge about the product and the organization, presents a technique to communicate with consumers, and it safeguards the quality of a product [6]. Packaging is an essential part of the product, it is almost impossible to find a product especially in the fast moving consumer goods (FMCG) that is sold without packaging. Taking into consideration the strong market competition, it is important to dedicate a special attention to product packaging, and adopt adequate changes in product packaging design and marketing to achieve positive market results [7]. Thus, businesses have to benefit from the interpretation of the packaging factors affecting customer preferences, and implement the necessary strategies that allow them to increase their sought market share.

According to [8]. Packaging has four distinct marketing functions: it contains and protects the product, it promotes the product, it helps consumers use the product and finally, packaging facilitates recycling and reduces environmental damage. Therefore, packaging does more than just protecting the company's product. When understanding its promotional role, packaging as a communication tool, is an important factor in the purchasing decision making process. It is becoming an ultimate selling tool, which stimulates impulsive purchases. Besides the product itself, the packaging is one of the main tools for in-store marketing [9].

In conclusion, failing to pay attention to the design of the package, can lead to undesirable results by decreasing the chances of being visible and attractive, which in turn will decrease the sales of the product and negatively affect the organization. Since, the ultimate goal for any business is to generate revenues, companies should take into consideration that packaging design can be used as a way of promoting the product/brand. It would also affect the buying behavior of consumers, which will result in higher revenues [10].

The packaging of a product plays an important role in attracting customers' attention to a specific brand, improving its image, and influencing consumers' perceptions of the product [11]. Moreover, packages give a special value for the product and strengthening its positioning in the market place [12]. Furthermore, packaging could help in differentiating the product and giving it uniqueness among other similar products [13]. As a result, focusing on the packaging elements can help the company in creating a positive image of its product. It can also lead to creating a product perceived by consumers as typical of its category.

A vital set of six elements that should be evaluated when employing packaging decisions; i.e. size, form, material, color, text and brand [14]. Thus, many packaging elements are factors that influence the buying behavior of consumers i.e., packaging color, packaging material, design of wrapper, and printed information. Color is an essential component of packaging, because consumers expect certain type of colors for particular products [3]. Besides, color perceptions vary across cultures and most of the religions are believed to have their sacred colors [15]. However, different colors symbolize different meanings to consumers. Additionally, colors and graphics play important roles in promoting product sales [16]. After all, to target the upper class customers, a company has to design a high level product exhibiting superior packaging elements, since the upper class customers care more about their self-image in society, and tend to choose the better looking product [17].

In addition to the previously mentioned elements, consumers' buying behavior can also be affected by the labeling of the product. Where, consumers tend to buy more quantities of a well labeled product [18]. The impact of consumer understanding and the information written on the product container i.e. "DANGER" warning was investigated by marketing researchers, and it was found that a customer can change his/her will to buy the product after reading the warning [19]. This means that understanding the label information has a direct influence on sales. Therefore, labelling the product is a determining factor in the purchasing 
decision of consumers.

Packaging contains and protects the product; hence it is also important to take into consideration the material used to package the product, in addition to, its design. Packaging material has a strong impact on the buying behavior of consumers. Consumers link the packaging material with certain essential values of the product [20]. It is assumed that the high quality material might attract customers more than low quality material. Additionally, consumer perceptions regarding certain materials could change the perceived quality of a product Therefore; the quality of packaging materials provides an image about the quality of the product itself. This relation should highlight the fact that packaging can be used as a strategic tool to achieve the business goals of commercial firms. Besides, packaging, nowadays, plays an important role in attracting customers' attention, and it acts as a strategic tool that influences the recognition of the quality of a product. The functions of packaging seem to provide information and facilitate communication with customers that are becoming more and more demanding [21]. Moreover, in recent years, most consumers have concluded that their buying behaviors directly affect environmental issues and this is one of the criterions that consumers consider when shopping. Environmental behavior includes efforts for saving energy and refusing to buy products with inappropriate packaging [22]. Finally, packaging is utilized as a space for delivering messages to influence consumers and their buying decisions. In marketing practice, brand stories are increasingly appearing on product packages. Brand stories included on packaging has a positive impact on consumers' affective, attitudinal, product value, and behavioral intention responses to the brand [23].

\section{Methodology}

This paper utilizes primary and secondary sources of data. A structured questionnaire represents the primary data source. Whereas, published scientific papers, journals, online articles, and books were used as secondary source of data.

The impact of packaging elements on consumer behavior was measured through data collection solicited from 150 respondents via a structured questionnaire. The dependent variable is the consumer buying behavior, and the independent variables are the elements of packaging (H1) and packaging quality (H2). Further, data analysis was obtained by using SPSS and Microsoft Excel software.

\section{Descriptive Statistics}

Upon the distribution of the structured questionnaires, 137 responses were collected, representing $91 \%$ of the respondents.

Table 1, summarizes the demographic characteristics of the respondents who participated in the survey of this paper. The paper included different age groups and different occupations of the respondents.
Table 1. Demographics.

\begin{tabular}{llll}
\hline \multicolumn{2}{l}{ Descriptive Statistics } & Frequency & Percent \\
\hline \multirow{2}{*}{ Gender } & Male & 95 & 69.10 \\
& Female & 42 & 30.90 \\
& Less than 20 & 13 & 9.60 \\
Age & $2-30$ & 68 & 49.90 \\
& $3-40$ & 32 & 23.00 \\
& $4-50$ & 21 & 15.20 \\
Job & more than 51 & 3 & 2.30 \\
& Student & 14 & 9.90 \\
& Business & 53 & 39.40 \\
& Education & 28 & 20.30 \\
Education & Other & 42 & 30.40 \\
& High School & 12 & 9.10 \\
& Bachelor & 66 & 47.70 \\
\hline
\end{tabular}

Table 2 and figure 1 show the frequencies and percentages of respondents regarding the variables that relate to the importance of packaging elements.

Table 2. Packaging color impacts consumer buying behavior.

\begin{tabular}{llll}
\hline Packaging color & & \\
\hline & & Frequency & Percent \\
\hline \multirow{4}{*}{ Valid } & Strongly disagree & 7 & 5 \\
& Disagree & 14 & 10 \\
& Neutral & 8 & 6 \\
& Agree & 76 & 56 \\
& Strongly Agree & 32 & 23 \\
& Total & 137 & 100 \\
\hline
\end{tabular}

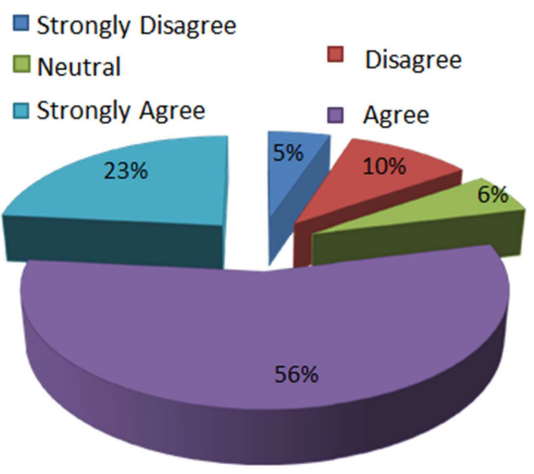

Figure 1. \% of respondents regarding the importance of packaging elements.

The above pie chart indicates that about $56 \%$ of the respondents agree that the color has an impact on buying behavior of consumers, and $23 \%$ strongly agree with this statement. However, only $5 \%$ of the respondents strongly disagree with this statement.

Table 3. Label of the package is important in the consumer buying process.

\begin{tabular}{llll}
\hline Packaging Label & & \\
\hline & & Frequency & Percent \\
\hline \multirow{4}{*}{ Valid } & Strongly disagree & 3 & 2 \\
& Disagree & 12 & 9 \\
& Neutral & 12 & 9 \\
& Agree & 66 & 48 \\
& Strongly Agree & 44 & 32 \\
& Total & 137 & 100 \\
\hline
\end{tabular}




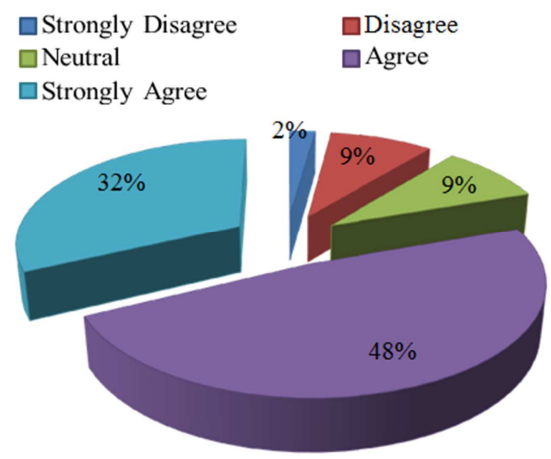

Figure 2. Package labelling importance.

The results obtained and presented in the above pie chart indicate that about $48 \%$ of the respondents agree that the label is an important factor regarding the consumer buying behavior, and $32 \%$ strongly agree with this statement. However, only $2 \%$ of respondents strongly disagree with this statement.

Table 4. Quality of the packaging material is important in consumer buying process.

\begin{tabular}{llll}
\hline Quality of Packaging Material & & \\
\hline & & Frequency & Percent \\
\hline \multirow{4}{*}{ Valid } & Strongly disagree & 3 & 2 \\
& Disagree & 11 & 8 \\
& Neutral & 7 & 5 \\
& Agree & 58 & 43 \\
& Strongly Agree & 58 & 42 \\
& Total & 137 & 100 \\
\hline
\end{tabular}

\section{$\square$ Strongly Disagree $\square$ Disagree \\ $\square$ Disagree \\ $\square$ Strongly Agree}

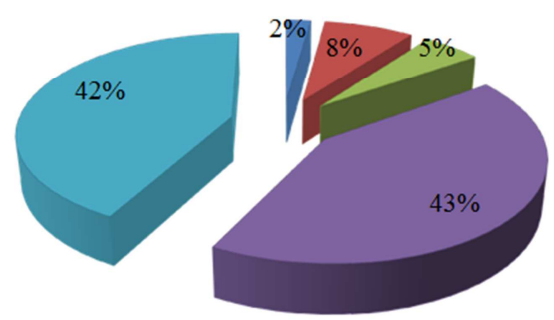

Figure 3. packaging quality.

The results obtained in the above pie chart indicate that about $43 \%$ of the respondents agree that the quality of packaging material is an important factor for the consumer buying behavior, and $42 \%$ strongly agree with this statement. Nevertheless, only $2 \%$ of the respondents strongly disagree with this statement.

Table 5. Package design has an impact on consumer buying behavior.

\begin{tabular}{llll}
\hline Package Design & & \\
\hline & & Frequency & Percent \\
\hline \multirow{4}{*}{ Valid } & Strongly disagree & 3 & 2 \\
& Disagree & 10 & 6 \\
& Neutral & 10 & 8 \\
& Agree & 66 & 50 \\
& Strongly Agree & 48 & 34 \\
& Total & 137 & 100 \\
\hline
\end{tabular}

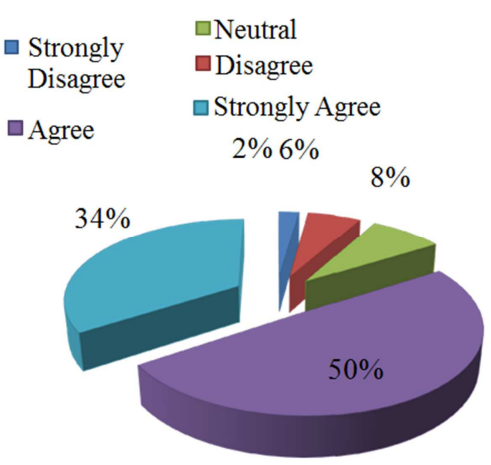

Figure 4. Impact of package design.

The above results (figure 4) state that about $50 \%$ of the respondents agree that package design has an impact on consumer buying behavior, and 34\% strongly agree with this statement. Only $2 \%$ of respondents strongly disagree with this statement.

Table 6. Printed information on the package is beneficial for the buying process.

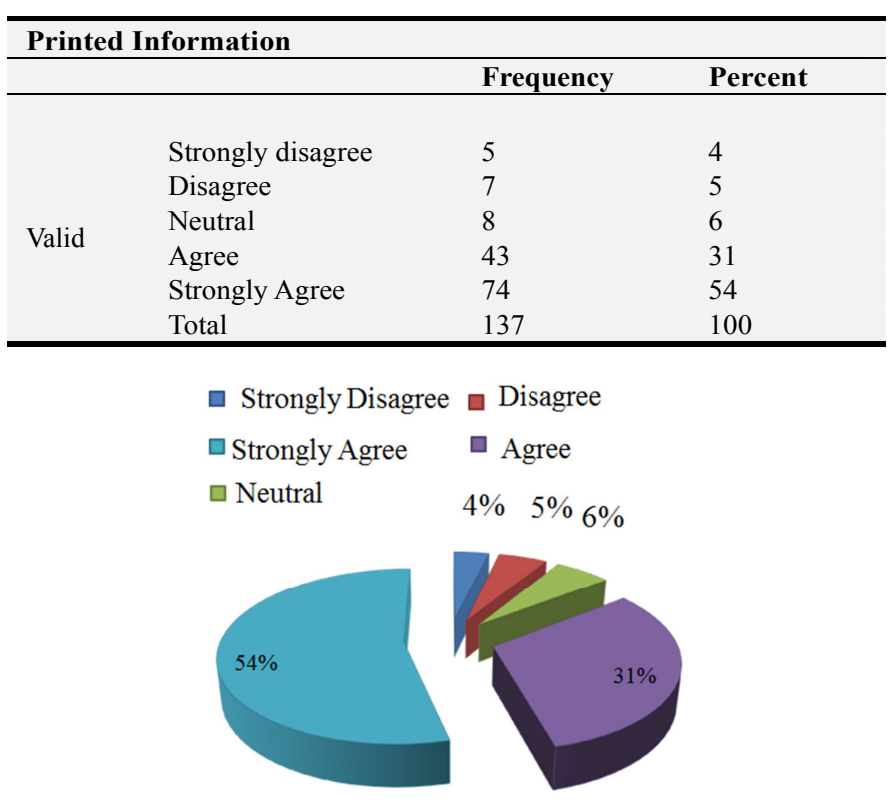

Figure 5. Package information.

The results obtained and presented in the above pie chart reflect that about $31 \%$ of the respondents agree that the printed information affects the buying behavior of consumers, and 54\% strongly agree with this statement. Only $4 \%$ of respondents strongly disagree.

Table 7. Language used on the package influences consumer buying behavior.

\begin{tabular}{llll}
\hline Packaging Language & & \\
\hline & & Frequency & Percent \\
\hline \multirow{4}{*}{ Valid } & Strongly disagree & 7 & $5 \%$ \\
& Disagree & 21 & $15 \%$ \\
& Neutral & 12 & $9 \%$ \\
& Agree & 45 & $33 \%$ \\
& Strongly Agree & 52 & $38 \%$ \\
& Total & 137 & $100 \%$ \\
\hline
\end{tabular}




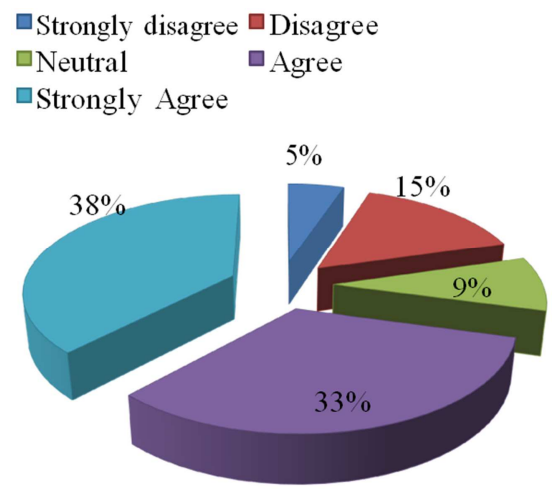

Figure 6. Language used on the package info.

The results in the above pie chart assert that about $33 \%$ of the respondents agree that the language influences the buying behavior, and 38\% strongly agree with this statement. Only $5 \%$ of respondents strongly disagree with this statement.

Table 8. Innovation in packaging design influences the consumer buying behavior.

\begin{tabular}{llll}
\hline Innovative Package Design & & \\
\hline & & Frequency & Percent \\
\hline \multirow{4}{*}{ Valid } & Strongly disagree & 4 & $3 \%$ \\
& Disagree & 8 & $6 \%$ \\
& Neutral & 15 & $11 \%$ \\
& Agree & 69 & $50 \%$ \\
& Strongly Agree & 41 & $30 \%$ \\
& Total & 137 & $100 \%$ \\
\hline
\end{tabular}

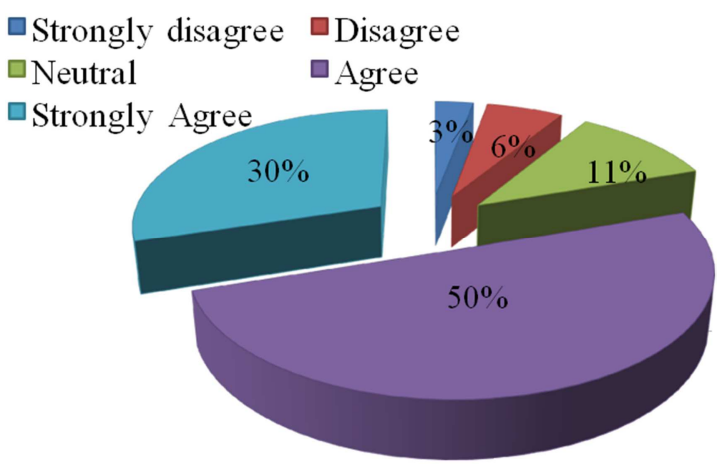

Figure 7. Impact of Innovation in Packaging.

The results obtained and presented in the above pie chart indicate that about $50 \%$ of the respondents agree that the innovation in packaging design is important for the buying behavior of the consumer, and 30\% strongly agree with this statement. Only $3 \%$ of the respondents strongly disagree.

\section{Empirical Statistics}

One Sample $\mathrm{T}$ Test was used to analyze packaging elements that have an impact on consumer buying behavior. The one-sample $t$ test shows whether a mean of a single variable differs from a specified constant.

Table 9. One Sample Statistics.

\begin{tabular}{|c|c|c|c|c|}
\hline & $\mathbf{N}$ & Mean & Std Deciation & Std Error Mean \\
\hline The packaging color impacts consumer buying behavior & 137 & 3.82 & 1.063 & 0.054 \\
\hline The label of the package is important in consumer buying process & 137 & 3.98 & 0.997 & 0.050 \\
\hline The quality of the packaging material is important in consumer buying process & 137 & 4.16 & 0.969 & 0.049 \\
\hline The package design has an impact on consumer buying behavior & 137 & 4.09 & 0.920 & 0.046 \\
\hline The printed information on the package if beneficial for the buying process & 137 & 4.26 & 1.010 & 0.051 \\
\hline The language used on the package influences consumer buying behavior & 137 & 3.87 & 1.210 & 0.061 \\
\hline The innovation in packaging design influences the consumer buying behavior & 137 & 4.01 & 0.960 & 0.048 \\
\hline
\end{tabular}

The results presented in the above one sample statistics table show the mean of population responses, standard deviation, and standard error. Mean value provides an idea about the central tendency of the values of a variable. Number of observations of each variable is 137. Standard deviation gives an idea about the dispersion of the values of a variable from its mean value. The minimum value is 1 , while maximum value is 5 .

The empirical findings should test the following hypotheses:

H1: Consumers' buying behavior is significantly affected by packaging elements.

$\mathrm{H} 2$ : Quality of packaging material has a considerable effect on the buying behavior of consumers.

With the null hypothesis, the means are the same, whereas with the alternative hypothesis the means differ. A big " $\mathrm{t}$ " ( $>$ +2.0 or $<-2.0)$, with a small p-value $(<0.05)$, denotes that the null hypothesis is rejected, and this would suppose that the means are significant. But a small " $t$ ", with a big p-value, denotes that the means are not significantly different.

Table 10. One Sample Test.

\begin{tabular}{|c|c|c|c|c|c|c|}
\hline & \multicolumn{6}{|c|}{ Test Value $=3$} \\
\hline & \multirow[b]{2}{*}{ t } & \multirow[b]{2}{*}{ df } & \multirow[b]{2}{*}{ Sig. (2Mean tailed) } & \multirow[b]{2}{*}{ Difference } & \multicolumn{2}{|c|}{$\begin{array}{l}95 \% \text { Confidence Interval } \\
\text { of the Difference }\end{array}$} \\
\hline & & & & & Lower & Upper \\
\hline The packaging color impacts consumer buying behavior & 15.236 & 137 & 0.000 & 0.815 & 0.71 & 0.92 \\
\hline The label of the package is important in consumer buying process & 19.526 & 137 & 0.000 & 0.980 & 0.88 & 1.08 \\
\hline $\begin{array}{l}\text { The quality of the packaging material is important in consumer } \\
\text { buying process }\end{array}$ & 23.874 & 137 & 0.000 & 1.165 & 1.07 & 1.26 \\
\hline The package design has an impact on consumer buying behavior & 23.625 & 137 & 0.000 & 1.094 & 1.00 & 1.18 \\
\hline
\end{tabular}




\begin{tabular}{|c|c|c|c|c|c|c|}
\hline & \multicolumn{6}{|c|}{ Test Value $=3$} \\
\hline & \multirow[b]{2}{*}{$t$} & \multirow[b]{2}{*}{ df } & \multirow[b]{2}{*}{ Sig. (2Mean tailed) } & \multirow[b]{2}{*}{ Difference } & \multicolumn{2}{|c|}{$\begin{array}{l}\text { 95\% Confidence Interva } \\
\text { of the Difference }\end{array}$} \\
\hline & & & & & Lower & Upper \\
\hline $\begin{array}{l}\text { The printed information on the package if beneficial for the } \\
\text { buying process }\end{array}$ & 24.767 & 137 & 0.000 & 1.258 & 1.16 & 1.36 \\
\hline $\begin{array}{l}\text { The language used on the package influences consumer buying } \\
\text { behavior }\end{array}$ & 14.310 & 137 & 0.000 & 0.871 & 0.75 & 0.99 \\
\hline $\begin{array}{l}\text { The innovation in packaging design influences the consumer } \\
\text { buying behavior }\end{array}$ & 20.864 & 137 & 0.000 & 1.008 & 0.91 & 1.10 \\
\hline
\end{tabular}

The obtained results from one sample $\mathrm{T}$ test presented in the above table, conclude that the following packaging elements (H1): packaging color, label of the package, package design, printed information, language used, and innovation in packaging design, have an impact on the buying behavior of consumers. In addition to the packaging elements, the quality of packaging material (H2) has an impact on the buying behavior too.

The calculated $\mathrm{T}$ for each of the items tested in the above table is greater than +2 with a $p$ - value of 0.00 less than 0.05 , indicating that this differences are significantly high at type I error of 5\%. Finally, the null hypotheses are rejected and the alternative hypotheses are accepted, indicating a strong relationship between the dependent variable: customer buying behavior, and the independent variables: packaging elements and quality of packaging material.

\section{Conclusion}

The obtained results in this research paper regarding the effect of packaging design on consumer's buying behavior stipulated the following conclusions:

1. The packaging elements are considered important tools of marketing communications towards consumers, since consumers pay attention to each element of the product package.

2. The packaging color can be considered one of the most striking elements of the product package, since it catches the consumers' attention at first sight. Certain colors can be associated with certain brand names and product trademarks. Therefore, the packaging color can influence the customers' purchasing behavior.

3. The packaging label provides significant information about the product itself. The research results concluded that the consumers value the information presented on the product package.

4. One of the other packaging elements is the printed information. It provides the necessary information related to the product quality, price, and description. Such information allows customers to spot the differences between several similar products.

5. It is very important to include several languages on the product package so that the product can be comprehended by a wide variety of customers. Hence the packaging language is a significant element that affects the consumer buying behavior.

6. Having an innovative packaging design is very important in competing with the various organizations providing similar products on one hand, and attracting and retaining the company's customers on the other.

The obtained results reflected that the packaging elements are very important during the buying process and they do facilitate to a great extent the buying decision process of consumers. Furthermore, the findings show that the following factors such as, the quality of the packaging material, Innovation, and practicality, the package design seem to be the most important factors for the product selection during the consumer buying process.

\section{Limitations}

This research fails to differentiate between different categories of products, and studying the impact of packaging on each category by itself. In addition, the distributed questionnaires tested the personal preferences of each individual without taking into consideration the real behavior upon purchasing a product. A third limitation is the absence of the impacts of the good product packaging on the price of the product, and its relative impact on the consumer buying behavior.

\section{Recommendations}

It is highly recommended that a further and more in depth study of the impact of the good packaging design on the price of the product is needed, for enhancing market competitiveness and sales volume. Moreover, the use further statistical testing such as correlation to test the impact of both price and packaging design on consumer buying behavior is greatly recommended

\section{References}

[1] Alvarez, A. \& Casielles, R. V. (2005), 'Consumer evaluation of sales promotion: The effect on brand choice', European Journal of Marketing 39(1/2), 54-70.

[2] Ahmed, Rizwan and Ahmad, Nawaz and Vishnu, Parmar and Khoso, Imamuddin, Role of Packaging and Labeling on Pakistani Consumers Purchase Decision (June 16, 2014). European Scientific Journal, June 2014 ed, Vol. 10, No. 16, EISSN 1857-7431.

[3] Keller, K. L., (2009). Choosing Brand Elements to build Brand Equity. Strategic Brand Management. 3rd ed. Delhi: Dorling Kindersley. Pp. 187-96. 
[4] Rundh, B., (2005). The multi-faceted dimension of packaging. British Food Journal, 107 (9), 670-684.

[5] Wells, L. E., Farley, H., \& Armstrong, G. A., (2007). The importance of packaging design for own-label food brands. International Journal of Retail \& Distribution Management, 35 (9), 677-690.

[6] Silayoi, P., \& Speece, M., (2007). The importance of packaging attributes: a conjoint analysis approach. European Journal of Marketing, 41 (11/12), 1495-1517.

[7] Gojko Vladić, Milica Kecman, Nemanja Kašiković1, Magdolna Pál, Mladen Stančić, (2015) Journal of Graphic Engineering and Design, Volume 6(2).

[8] Charles W. L, Joe F. H, Carl M., (2011). Essentials of Marketing: A Marketing Strategy Planning Approach, Cengage Learning.

[9] Schoormans, J. P. L. and Robben H. S. J. (1997): The effect of new package design on product attention, categorization and evaluation. Journal of Economic Psychology, Volume 18 , Issues 2-3, pp. 271-287.

[10] Deliya, M. M. \& Parmar, B. J. (2012), 'Role of packaging on consumer buying behavior: Patan District', Global Journal of Management and Business Research, Vol. 12 (10), ISSN: $122-137$.

[11] Kuvykaite, R., Dovaliene, A., and Navickiene, L. (2009). Impact of Packaging Elements on Consumers' Purchase Decision, Kauno Technologijos Universitetas (KTU).

[12] Underwood, R. L., Klein, N. M., \& Burke, R. R., (2001). Packaging communication: attentional effects of product imagery. Journal of Product \& Brand Management, 10 (7), 403-422.

[13] Silayoi, P., and Speece, M. (2004). "Packaging and purchase decisions: An exploratory study on the impact of involvement level and time pressure", British Food Journal, Vol. 106 Issue: 8, pp. 607-628.
[14] Kotler, P. and Keller, K., (2006). Marketing Management (14th edition). London: Pearson Education.

[15] Singh, S. (2006). "Impact of Color on Marketing" Management Decision VOL44. Issue: 6, pp. 783-789.

[16] Behzad M. (2014). "The art of packaging: An investigation into the role of color in packaging, marketing, and branding", International Journal of Organizational Leadership pp. 92102.

[17] Baik S. (2011). "Package design management in SMEs", Diversity and Management, pp: 1-6.

[18] Saeed, R., Lodhi, R. N., Rauf, A., Rana, M. I., Mahmood, Z., and Ahmed, N. (2013). Impact of Labelling on Customer Buying Behavior in Sahiwal, Pakistan, World Applied Sciences Journal, Vol:24(9), ISSN:1250-1254.

[19] Spink, A., Heinström, J. (2011), Information Behavior Development in Early Childhood, in Amanda Spink, Jannica Heinström (ed.) New Directions in Information Behaviour (Library and Information Science, Volume 1) Emerald Group Publishing Limited, pp. 245 - 256.

[20] Smith, P. R. \& Taylor, J., (2004). Packaging in Marketing Communications. London: Kogan Page Limited.pp. 543- 74.

[21] Ahmed, R. R., Parmar, V. and Amin, M. A. (2014). European Journal of Scientific, 120 (2): 145-157.

[22] Esmaeilpour, Majid and Rajabi, Azade (2016) "The Effect of Environment-Friendly Attitude on Consumer Perception of Usability of Product Packaging," Journal of Applied Packaging Research: Vol. 8: No. 2, Article 6.

[23] Solja, E., Liljander, V. and Soderlund, M. (2018). Short Brand Stories on Packaging: An Examination of Consumer Responses. Psychology and Marketing. Volume 35, Issue 4, pp. 294-306. 